\title{
Anders Engberg-Pedersen
}

\section{Serious games}

\section{Harun Farocki og den militære æstetik}

all but war is simulation

STRICOM

the real economy is an aesthetic economy

Harun Farocki

jeg anbefaler æstetiske øvelser

Alexander Baumgarten

\section{Introduktion}

I 2009 kørte en gruppe amerikanske marinesoldater deres tank gennem ørkenen i Twentynine Palms, Californien, da et eller andet syntes at blokere vejen. ${ }^{\mathrm{I}}$ Objektet lignede ikke noget, de var trænet til at identificere, og manglen på genkendelse fik dem til at standse (fig. 1). De indså dog hurtigt, at det sandfarvede, trekantede objekt ikke var virkeligt. Lidt efter kørte de videre.

Soldaternes var i gang med et såkaldt "serious game." Deres tank befandt sig i Virtual Battle Space 2 - en simulation, som er designet til at give soldater en immersiv, virtuel krigserfaring, inden de bliver sendt i felten. Sikkert forskanset på deres base i Californien befandt marinesoldaternes tanker og kroppe sig på samme tid inde i basens Battle Simulation Center, hvor de kørte af sted på et virtuelt terræn genereret af virkelige kartografiske data fra en potentiel krigszone. Et øjeblik troede soldaterne, at objektet var en vejsidebombe, en såkaldt IED (Improvised Explosive Device). Det blev snart klart, at der bare var tale om en harmløs fejl i softwareprogrammet. Nogle pixels, der viste ørkensandet, var blevet kopieret ind oven på asfaltvejen. Men i virkeligheden var de der ikke. Denne fejl er udgangspunktet for Harun Farockis videoinstallation Serious Games I-IV fra 2009-2010. 
Gennem flere årtier fulgte den tyske dokumentarist og installationskunstner Harun Farocki den teknologiske udvikling af krigens billeder. Hans tidlige film Nicht Löschbares Feuer/The Inextinguishable Fire (1969) om Vietnamkrigen og Bilder der Welt und Inschrift des Krieges/Images of the World and the Inscription of War (1989) om luftfotos af Auschwitz blev efterfulgt af en undersøgelse af det, han kaldte "operative billeder" med Auge/Maschine/Eye/Machine (2000-2003). Operative billeder dukkede op under den første Golfkrig og er karakteriseret ved at være rent funktionelle: De skal ikke ses af mennesker, men bliver udelukkende læst af maskiner. I de senere år vendte Farocki sin opmærksomhed mod de krigssimulationer, som for tiden udspiller sig i immersive virtual reality-krigsspil. Siden 1990'erne, hvor Dwight D. Eisenhowers berømte "military-industrial complex" gradvis forvandlede sig til et "military-entertainment complex" (Lenoir og Lowood 2005) eller til det såkaldte "military-industrial-media-entertainment network" (MIME-NET), som James Der Derian har døbt det (Der Derian 2009), har førende militærmagter brugt store summer på udviklingen af virtual reality-krigsspil såsom Virtual Iraq og Virtual Afghanistan i et tæt samarbejde med videospil- og filmindustrien. Spillene tilbyder kunstig krigserfaring - de producerer erfaringseffekter med virtuelle midler.

Det er imidlertid langt fra klart, hvordan vi skal forstå denne erfaring. Hvad sker der med andre ord med traditionelle forståelser af "erfaring" med fremkomsten af immersive VR-teknologier? Hvordan organiserer det teknologiske udstyr soldaternes perception og erindring og organiserer dem med henblik på fremtidig handlen? Hvordan eksperimenterer dets designere med brugernes sanser, og hvilken formatering af sanserne forsøger de at effektuere? Det er nogle af spørgsmålene, som Harun Farockis videoinstallation Serious Games rejser.

Installationen blev først vist på São Paolo Biennalen i 2010, og den dokumenterer kritisk den prekære sammenfletning af virtuel krig og faktisk krig. Dens tentative undersøgelser afslører, hvordan krigen i det 21. århundrede i hidtil uset grad er kommet til at handle om æstetik. Militærunderholdningskomplekset, MIMENET, eller hvad vi nu vælger at kalde samarbejdet mellem militære institutioner

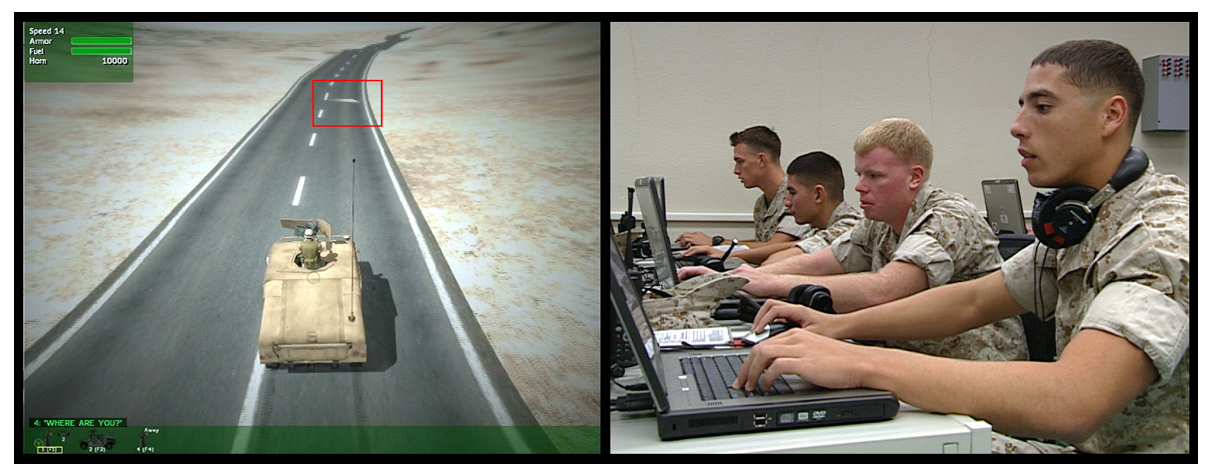

Fig. 1. (C) Harun Farocki GbR 
og kulturindustrien, har udviklet et æstetisk regime som i stigende grad former den måde, Vesten fører krig på i dag. Ved hjælp af avancerede simulationer, hvor fiktionelle verdener reorganiserer soldaters perception, har militæret bevæget sig ind på et område, man ikke plejer at forbinde med militære operationer - æstetikken. Farockis installation fungerer som en art indeks for fremkomsten af et militæræstetisk regime, hvor det æstetiske, som vi normalt forbinder med kunsten, er blevet overtaget og militariseret.

Med Farocki som guide placerer min artikel Serious Games i krigssimulationens historie og i den æstetiske teori med det formål at skitsere anatomien af samtidens militære æstetik og dets konsekvenser for vores forståelse af krigserfaringen. Jeg afdækker først de institutionelle samarbejder mellem militæret og kulturindustrien for så at se nærmere på et afgørende øjeblik i krigsteknologiens historie: opfindelsen af det moderne krigsspil omkring år 1800 og erstatningen af tekster med spil som militærets foretrukne erfaringsteknologi. Vi får en bedre fornemmelse af den nye erfaringsform, hvis vi betragter den i lyset af klassisk og nyere æstetisk teori. Jeg vender derfor blikket mod Alexander Baumgarten, John Dewey og Jacques Rancière for med deres refleksioner over æstetik, erfaring og politik at etablere en ramme for de seneste årtiers samarbejde mellem militæret og kulturindustrien. Til sidst vender jeg tilbage til vores guide, Harun Farocki, og undersøger effekterne af militærets overtagelse af æstetikken på kunsten selv ved at forfølge de vanskeligheder, Farocki har med at vriste æstetikken fri af militærets greb.

\section{Kreativ krigsførelse}

En milepæl i fremkomsten af den militære æstetik var grundlæggelsen af Institute for Creative Technologies (ICT) på University of Southern California i Los Angeles. I 1999 gav det amerikanske forsvarsministerium, Department of Defense, universitetet en femårig kontrakt på 45 millioner dollars. Midlerne skulle sponsorere et center, hvor universitetsforskere ville indgå i et samarbejde med hærens forskningsenhed, US Army Research Laboratory. Ved åbningsceremonien stod universitetets rektor skulder ved skulder med lederen af den amerikanske hær, med direktøren for Silicon Graphics, præsidenten for the Motion Picture Association of America, Los Angeles' viceborgmester samt Californiens daværende guvernør, Gray Davis, som var virtuelt til stede på en skærm beamet ind via satellit fra Sacramento. ${ }^{2}$ Formålet med dette samarbejde mellem militæret, Hollywood, spilindustrien, den politiske verden og uddannelsesinstitutionerne var, med deres egne ord: "[to bring] film and game industry artists together with computer and social scientists to study and develop immersive media for military training, health therapies, education and more" (ICT 2014). ICT har siden fået tre nye kontrakter. Den sidste beløb sig til 135 millioner dollars. I løbet af de sidste snart tyve år har centret produceret et antal immersive medier og syntetiske miljøer, som gradvis er blevet taget $\mathrm{i}$ anvendelse af den amerikanske hær. ${ }^{3}$

Et af produkterne var virtual reality-krigsspillet Full Spectrum Warrior, som blev udviklet i samarbejde med det uafhængige firma Pandemic Studios. Da mange teenagere bruger timevis på at spille computerspil, forsøgte ICT at udnytte deres 
praktiske viden og vaner til militær træning. Full Spectrum Warrior er et krigsspil, dvs. en simulation, som skal give rekrutter krigserfaring ved hjælp af en immersiv oplevelse i en virtuel verden, hvor de kan træne taktik, beslutningsprocesser, koordinering osv. uden fare for den faktiske krigs skadelige konsekvenser. Men sådanne spil foretager også et raffineret affektivt management. I Farockis første installation, Serious Games I: Watson Is Down, viser den venstre side af den todelte skærm simulationen "Virtual Battle Space 2," mens den højre side viser soldaterne, der sidder foran deres computere og spiller spillet. Soldaterne bliver angrebet, men deres reaktioner er mærkeligt afdæmpede. I baggrunden ler andre spillere, og de virker uengagerede og følelesmæssigt afkoblede fra de virtuelle begivenheder, der udspiller sig foran dem. Flere soldater ser ud til at kede sig og stirrer stift på skærmen. Da Watsons avatar i spillet pludselig bliver skudt og dræbt og falder ned fra køretøjet, sukker Watson og skubber sig langsomt væk fra computeren (fig. 2).

Fraværet af følelser er ikke tilfældigt. Det er den kalkulerede effekt af en omhyggeligt kalibreret affektiv kontrol designet til at træne ikke bare soldaternes kroppe, men også deres sind. Dr. Albert "Skip" Rizzo, der er forskningsprofessor på ICT, har udviklet to projekter, som bruger immersiv VR-teknologi til at administrere og kontrollere menneskets reaktion på den ekstreme erfaring, som krig er. Det første af dem, Stress Resilience in Virtual Environments, eller STRIVE, er et VRtræningsprogram, som optimerer den psykologiske respons på krig. Præmissen er, at en virtuel eksponering for visse typer og grader af stress kan forbedre soldaternes "resilience," deres modstandsdygtighed eller robusthed, dvs. hvor hurtigt og effektivt de vender tilbage til en normal psykologisk tilstand efter kampens stress. Den blasé attitude - den mentale indstilling, som dæmper påvirkningen af ydre sansedata, som Georg Simmel engang diagnosticerede som den urbane modernitets overlevelsesstrategi - er i moderne krig blevet resultatet af systematisk træning (Simmel [1903] 1972). ${ }^{4}$

Det andet projekt, Virtual Reality Exposure Therapy, eller VRET - temaet for Farockis tredje installation, Serious Games III: Immersion - er designet til soldater, der vender hjem fra krigen med PTSD. ${ }^{5}$ Ved at placere soldaterne i virtuelle scenarier

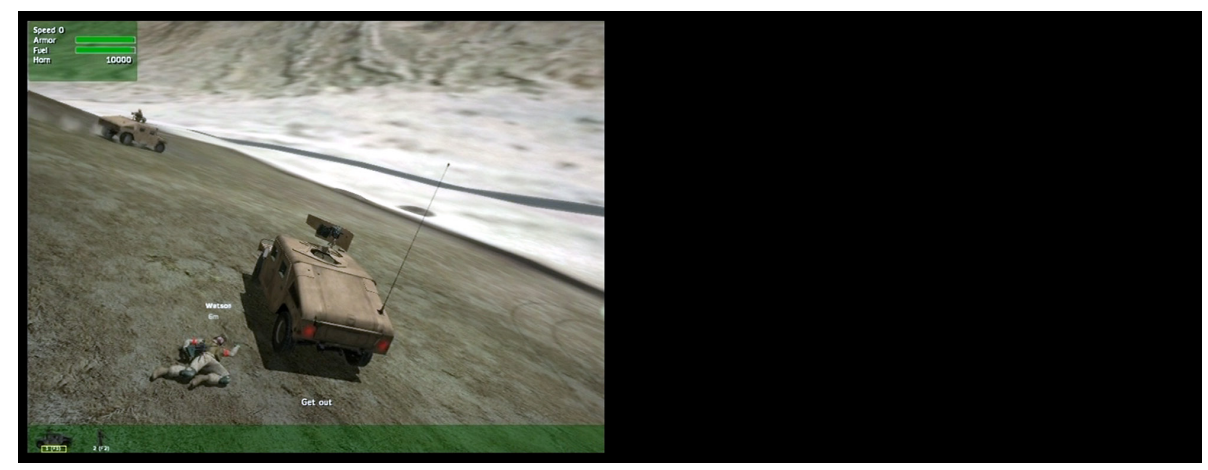

Fig. 2. (C) Harun Farocki GbR 
af mellemøstligt tilsnit, forsøger prototyper som Virtual Iraq eller Virtual Afghanistan at ændre forbindelsen mellem sanseindtryk og affektiv respons for at hjælpe soldaterne til at overvinde traumer (fig. 3). Først genoplever soldaten/patienten traumet, mens han angiver graden af sin sindsbevægelse på en såkaldt "Subjective Units of Disturbance Scale" (SUDS). Soldaten/patienten bliver dermed resensibiliseret for at kunne bearbejde traumet. Ved at gennemspille traumet adskillige gange desensibiliseres soldaten igen, så han kan vende tilbage til en stabil tilstand (allostasis). ${ }^{6}$ Med andre ord er det den samme VR-teknologi, som bliver brugt både før og efter kamp i et forsøg på at kontrollere og administrere den psykologiske respons på ekstreme erfaringer. Som Farocki tørt bemærker, er den eneste forskel, at den terapeutiske traumesimulation ikke simulerer skygger, fordi softwareprogrammet er lidt billigere end det i kamptræningssimulatoren.

Den kalkulerede administration af følelser og sanser opnås kun ved hjælp af en kreativ æstetik, som låner meget fra filmbranchen og spilindustrien. Den tyske medieteoretiker Friedrich Kittler argumenterede gennem det meste af sit liv for, at krig er den afgørende faktor for udviklingen af medier, og at civile teknologier blot er hackede versioner af medier, der oprindeligt blev opfundet til militære formål.7 De seneste årtier er bevægelsen imidlertid gået i den anden retning. En vigtig grund til, at den amerikanske hærs simulations- og udviklingsafdeling indgik et samarbejde med ICT i Los Angeles, var, at underholdningsindustrien var langt foran militæret i udviklingen af simulationer, virtual reality og special effects. I de sene 90'ere anvendte STRICOM (den amerikanske hærs "Simulation, Training, and Instrumentation Command") $)^{8}$ en trådløs teknologi, som var blevet udviklet af Hollywood ti år tidligere til film som Batman (1989) og Aliens (1986). Mange af de simulationer, militæret har udviklet, er ligeledes baseret på kommercielle videospil som Doom, hvor monstrene er blevet erstattet med fjendtlige styrker (Der Derian 2009, 87-89). ${ }^{9}$ Således supplerede Dr. Rizzos VRET projekt den traditionelle behandling (samtaleterapi) med en teknologisk komponent fra spilindustrien (fig. 4). Som hans forskningsteam formulerer det: "ICT researchers added to this therapy by leveraging virtual art assets that were originally built for the commercially

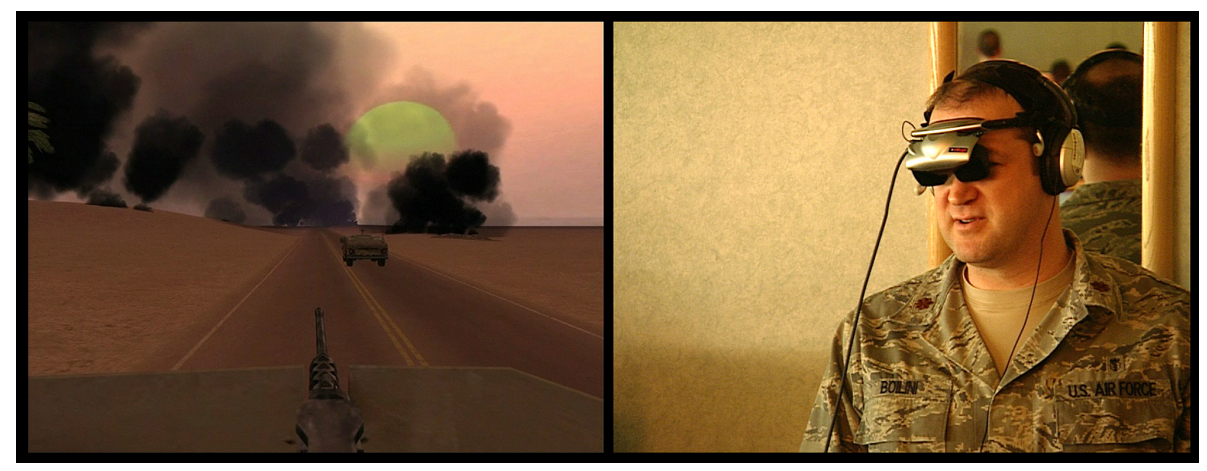

Fig. 3. (C) Harun Farocki GbR 
successful X-Box game and combat tactical simulation scenario, Full Spectrum Warrior" (ICT 2015a). De virtuelle ressourcer fra kunstens verden inkluderer "advanced gaming development software, cinematically designed lighting and sound and narrative that maximizes character development and emotional engagement as well as clinical appropriateness" (ICT 2015b). ${ }^{\text {Io }}$

Farockis installation illustrerer den nye militære æstetik, som er vokset frem af denne sammenfiltning af underholdningsindustrien, virtual reality, og krigsinstitutionerne. I dag spiller æstetikken en central rolle i planlægningen, udførelsen og behandlingen af krig. Den indgår som en del af en digital avantgarde, hvor avantgardebegrebets militære og æstetiske betydning endelig er smeltet sammen og udgør fortroppen i krigsproduktionen. Som de fire videoer i installationen viser, forbinder det militær-æstetiske regime to standardbetydninger af begrebet æstetik. På den ene side er VR-simulationernes æstetik et spørgsmål om design, om at bygge overbevisende fiktive verdener ud af den binære kodes et'er og nuller. På den anden side har det at gøre med den oprindelige græske betydning af aisthesis: sansning og perception. Træningssimulationer som dem, vi ser i Serious Games I, er designet til at opbygge en tolerance over for ekstreme erfaringer, til at bevirke en præventiv anæstesi. Som man kan aflæse af Watsons afdæmpede reaktion på hans egen virtuelle $\mathrm{d} ø \mathrm{~d}$, fusionerer sådanne spil lækkert design og sanseperception til en an-æstetik. Ved at justere lyset, computergrafikken og lydeffekterne kan den teknologisk udrustede militærpsykolog genskabe krigens sanseerfaring - dens syn og lyde, lugte og vibrationer - for at desensibilisere soldaternes sanseapparat, inden de bliver sendt ud, for så at resensibilisere de hjemvendte soldater under virtual reality exposure therapy med den optimale simulation designet til deres individuelle behov, som vi ser det i Serious Games III. Med Rizzos ord: "Now rather than relying exclusively on imagining a particular scenario, a patient can experience it again in a virtual world under very safe and controlled conditions" [min fremhævning].

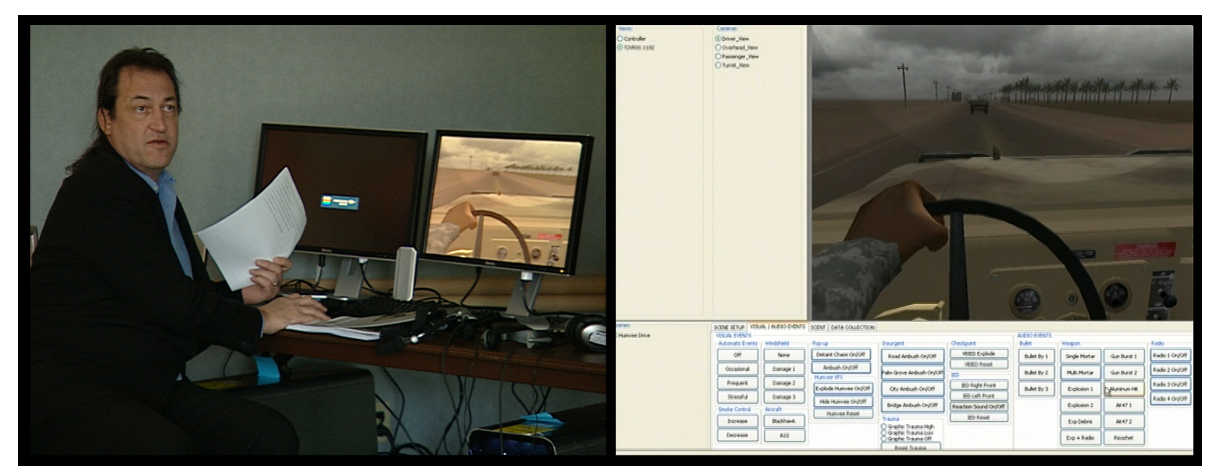

Fig. 4. (C) Harun Farocki GbR 


\section{Erfaringsteknologier}

I mange henseender er det ikke noget nyt. Mellem 1770 og 1830 udviklede et antal opfindere den første brugbare krigssimulation, eller på prøjsisk: das Kriegsspiel. Opfindere som Hellwig, Venturini, Allgaier, Chamblanc, Opiz, Reißwitz og andre designede et antal stadig mere intrikate krigsspil for med kunstige midler at gengive krigens karakter og dynamik i en simuleret verden. Som titlen på et af disse krigsspil indikerer - Det Opiz'ske Krigsspil, Et Bidrag til Dannelsen af Kommende og til Adspredelsen af selv de mest erfarne Taktikere (Das Opiz'sche Kriegsspiel, ein Beitrag zur Bildung künftiger und zur Unterhaltung selbst der erfahrensten Taktiker) - fokuserede disse spil primært på den taktiske organisering af krigen og forsøgte også at lære officererne, hvordan man håndterede dens komplekse epistemologiske orden. En afgørende innovation i krigsspillets historie var Opiz' introduktion af terninger, hvilket bragte en usikkerhedsfaktor ind i spillet og fordrede beslutninger baseret på sandsynligheder. ${ }^{\text {II }}$

For to hundrede år siden var det imidlertid et andet medie, som havde til opgave at simulere krigserfaringens følelser og sansninger. I Vom Kriege, der udkom posthumt i 1832, hævder Carl von Clausewitz, at kun "levende" repræsentationer kan formidle kamperfaringen, og han mente, at det medie, der bedst kunne generere denne form for repræsentation, var den skrevne tekst (Clausewitz 1980, 462, 369). I modsætning til den mere rationelle træning i krigsspillene, som blev spillet med terninger på todimensionelle topografiske kort, anbefalede Clausewitz sine officerer at læse historiske beretninger og litteratur. I en paragraf om krigens farer opfinder han oven i købet et detaljeret fiktivt scenarie, som skal illustrere, hvordan krig erfares fra en ny rekruts perspektiv. Forsøget på at gengive bombardementet af sanserne så realistisk som muligt er paradigmatisk for den efterfølgende udvikling af litteraturhistorien. Det 19. århundredes realistiske krigsroman fra Balzac til Tolstoj via Stendhal forsøger at udvikle en poetik, som kan skabe en simuleret, immersiv oplevelse af krig (Engberg-Pedersen 2015). Clausewitz' russiske oversætter, Mikhail Ivanovich Dragomirov, hævder således, at de fiktive narrativer i Krig og Fred ville være "en af de mest brugbare supplementer til ethvert teoretisk seminar om kunsten at føre krig" (Dragomirov 1898, 7).

Det har VR ændret. Som Farocki formulerer det i et interview: "Perhaps fifty years ago there would have been a novel by a smart American; he'd have written a novel about the experience in Iraq, as with the Phillip Roth generation, the postWorld War II generation of writers" (ten Brink og Oppenheimer 2012, 69). I dag har VR-krigsspil erstattet både tekst og traditionelle 2D-krigsspil som militærets foretrukne erfaringsteknologi. Man kunne sige, at VR er en fusion af de to tidligere teknologier: én, som simulerede taktik og kontingens - 2D-krigsspillene; og én, som formaterede sanserne og følelserne ved at udsætte dem for et gentagent virtuelt bombardement - litterære og historiske tekster. ${ }^{\mathrm{I2}}$ Med svag overdrivelse har militærhistorikeren Martin van Creveld engang sagt, at omkring $1800 \mathrm{blev} \mathrm{krig}$ ført på kortet (van Creveld 2000, 94-95). I dag kunne vi sige, at krig i stigende grad føres i VR-simulationer. Pointen er selvfølgelig ikke, at VR har erstattet virkeligheden med en uendelig vækst af simulakrer, som en for hastig læsning af Baudrillard kunne antyde. Den er derimod, at virkeligheden ikke længere står i opposition til 
simulationer, men at den - på godt og ondt - inkluderer dem. Når vores repræsentationer af krigen bliver de midler, krigen udkæmpes med, må vi udvide vores begreb om det virkelige, ikke skrumpe det. Som Farockis Serious Games gør klart, udgør kropslige, immersive simulationer en integreret del af det, vi nu må forstå som det militært virkelige. Og installationen peger på det faktum, at denne udvidede militære virkelighed er organiseret æstetisk. Hvis VR-krigsspil kan betragtes som en fusion af to historiske erfaringsteknologier, så er denne udvikling ikke så overraskende, for både i krigsspillets og i krigsromanens historie har krig været et spørgsmål om design og følelser: om karakterudvikling, atmosfære og plot, om produktionen og manipulationen af billeder, sansninger og følelser (Engberg-Pedersen 2015). Farockis installation fremhæver netop i hvor høj grad disse to teknologier har bragt æstetikken ind i hjertet af krigsførelsen.

\section{Den militære æstetik}

Men kan vi være lidt mere præcise omkring den æstetiske karakter af nutidens krigsførelse? Jacques Rancières ideer om den underliggende affinitet mellem politik og æstetik er brugbare i den forbindelse. Ifølge hans velkendte teori består de to felters fællesnævner i det, han kalder "distributionen af det sanselige" - altså måden, hvorpå både politiske aktører og kunstværker opdeler og organiserer fælles sanselige erfaringer. I den optik består politik ikke primært i udøvelsen af magt eller i kampen om magt. Det består i måden, hvorpå tid og rum konfigureres materielt og symbolsk, i valget af objekter og mennesker, som befolker dette rum, og det placerer magten hos de individer, som besidder positionen og evnen til at beskrive det. Det er denne primære akt, hvor verden konfigureres, som for Rancière udgør "det politiskes æstetik." Omvendt består "æstetikkens politik” ikke i en given romans eller films tematik eller politiske budskab, ej heller i repræsentationen af bestemte sociale grupper, samfundsstrukturer eller konflikter. Den består i de måder, hvorpå kunsten rekonfigurerer og suspenderer både sanseerfaringens hverdagsformer og de æstetiske former, som den politiske måde at organisere verden på skaber. Kunsten er altid politisk og emancipatorisk, fordi den etablerer alternative måder at organisere verden på, nye konfigurationer som konkurrerer med politikens konfigurationer. Og dermed skaber den et rum for dissens (Rancière 2000, 2004a).

I Rancières diskussion af det æstetiske felt opholder han sig mest enten ved den politiske sfære eller ved kunstens traditionelle område, og han behandler kun sjældent, hvordan postindustrielle, digitale teknologier producerer sensibilitet (Stiegler 2014). Det kan imidlertid være frugtbart at udvide hans indsigter til samtidige VR-simulationer, for de fremhæver militærets forvandling af æstetikken. Sammenfaldet mellem kulturindustrien, digitale teknologier og krigens institutioner har udviklet en tredje kategori, som udvisker forskellen mellem det politiskes æstetik og æstetikkens politik. I samtidens militær-æstetiske regime er den organisatoriske kraft, som Rancière finder i kunstværket, blevet overtaget af militæret, som dermed har forvandlet det æstetiske værk til et politisk instrument. Krigsspil som Full Spectrum Warrior og Virtual Battle Space 2 erstatter adskillelsen mellem 
det æstetiske værks symbolske konfiguration af verden og den institutionaliserede, politiske konfiguration med en mimetisk relation. Der er ikke tale om en mimetisk relation i betydningen krigspropaganda, selvom det også spiller en rolle. ${ }^{13}$ Immersive VR-krigsspil iscenesætter bestemt magt og mobiliserer masserne - fortrinsvis teenagedrenge - men de er ikke først og fremmest eksempler på æstetiseringen af politik i Walter Benjamins forståelse af relationen. Deres kraft ligger snarere i konstruktionen af en virtuel verden, som konfigurerer og træner brugerne i at se og sanse verden på en bestemt måde.

Den mission, som soldaterne i Serious Games I og Serious Games IV spiller, hedder for eksempel Recognition of Combatants - Improvised Explosive Devices (fig. 5). Farockis video viser en instruktør i færd med at udvælge forskellige beholdere til de såkaldte IED'er fra en dropdown-menu såsom cementblokke, coladåser, papkasser og døde dyr ("dead dog 1" eller "dead dog 2"), lige som han udvælger fjenderne, der skal optræde i spillet. Nogle er ubevæbnede og ligner civile, andre bærer militærveste, hætter og tørklæder. Trods valgmulighederne og en vis grad af variation kan instruktøren kun vælge blandt et fast antal objekter, som programmørerne af simulationen har bestemt. Softwareprogrammets valgmuligheder danner et digitalt a priori for spillernes verden. Hvad enten vi kalder dem for stereotyper eller skemaer, udgør formen og designet af disse stiliserede billeder den virtuelle verden, som soldaterne bevæger sig rundt i. Som træningsredskab er simulationen baseret på en reduktion af perceptuel kompleksitet og etablerer en række mentale skemaer, der efterfølgende kan appliceres i felten. Som Lucy Suchman skriver i forbindelse med ICT's Flatworld-projekt, opfører militære simulationer den virkelighed, de citerer, ved at skabe fjenden som den performative effekt af et regulativt ideal (Suchman 2016, 26-27). Men det er ikke bare fjenden, der er et produkt af den måde, simulationen distribuerer sanselige objekter og konfigurerer den immersive matrix. Det er hele perceptionen af krigen - hvad spillerne ser, hører og føler. Og alt dette befinder sig i hænderne på computerprogrammører i spilindustrien.

Hvad mere er, siden immersive VR-krigsspil ikke bare er repræsentationer, som man kan betragte mere eller mindre passivt, men interaktive simulationer som

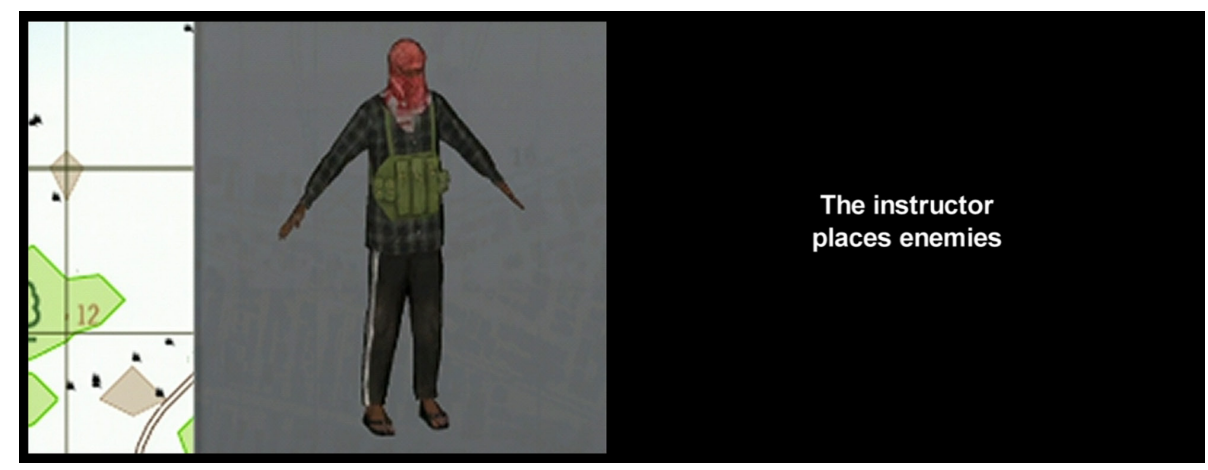

Fig. 5. (C) Harun Farocki GbR 
kræver spillernes deltagelse, udgør de et effektivt redskab til at overføre deres konfiguration af verden samt den sanselige erfaring af den til spillerne/soldaterne. For som spilteoretikere minder os om, kan spillets billeder og lyde meget vel være virtuelle, imen spillernes handlinger er virkelige. I hver gennemspilning indprenter spillet aktivt sin æstetiske orden via soldaternes beslutninger og handlinger. Gentaget igen og igen i træningscenteret i Twentynine Palms bliver den fiktive konfiguration af tingene i Virtual Afghanistan og Virtual Iraq til sidst en integreret del af soldaternes reflekser, motoriske hukommelse og mentale setup, indtil de er klar til at se og agere i verden i det faktiske Afghanistan og Irak.

I sin undersøgelse af forholdet mellem æstetik og politik er Rancière optaget af æstetikkens potentiale, men han bekymrer sig mindre om, hvordan kunstneriske former for dissens kan realiseres og faktisk gøre en forskel for den måde, vi organiserer de mange dimensioner af vores fælles verden. Krigsspil går et skridt videre. Soldaternes aktive engagement med fiktive verdener giver deres æstetiske rekonfiguration en praktisk kraft. Ved at generere en sanseerfaring af en bestemt konfiguration af verden og ved at træne soldaterne i at implementere den, realiserer immersive VR-krigsspil halvvejs kunstens latente potentielle kraft ved at ændre brugernes habitus. Med andre ord - den militære æstetik korrelerer ikke sandhed og skønhed, men simulation og effektivitet. Det gør spillet "alvorligt" for så vidt, at det fungerer som en katalysator for reelle forandringer i den virkelige verden. I militærets opdaterede version fungerer æstetikken som et træningsredskab.

\section{4. Æstetisk træning}

Den æstetiske træning, der finder sted i moderne krigsspil, følger en over 250 år gammel anbefaling fra grundlæggeren af æstetikken som disciplin. I tredje del af Aesthetica (1750) anbefaler Alexander Baumgarten det, han kalder "EXERCITATIO AESTHETICA" - æstetiske øvelser - for at udvikle og kalibrere sanseapparatet:

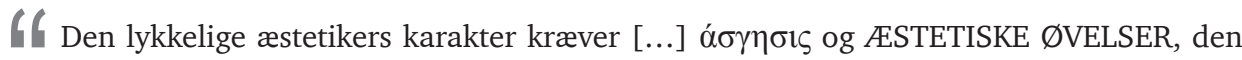
hyppige gentagelse af ens handlinger, så der eableres en korrespondance mellem sindet og karakteren [...] i forbindelse med et givent tema [...] mere præcist i forbindelse med kun ét objekt som skal forestilles, kun én ting, så evnen til at tænke smukt langsomt erhverves. (Baumgarten 2007, 38-39)

Den smukke tanke består for Baumgarten i en formel korrespondance mellem kognitionen og tingene i verden, mellem den mentale repræsentation af et objekt og objektet selv. Den grimme tanke manifesterer sig på den anden side, når korrespondancen er utilstrækkelig eller helt fraværende. For at blive en felix aestheticus skal man kaste sig ud i æstetiske øvelser, som træner sindet i at percipere verden korrekt. For Baumgarten er perceptionen ikke bare givet, men en evne der kræver æstetisk træning.

Men øvelserne behøver ikke være perfekte. Baumgarten kræver kun, at de udviser "en vis lighed", og han accepterer øvelser, som kunne korrumpere den smukke korrespondance en anelse. I visse tilfælde tillader han endda øvelser, hvis grimhed 
er større end deres skønhed (altså, øvelser hvor de mentale repræsentationer har flere utilstrækkelige end tilstrækkelige korrepondancer). Men Baumgarten vil kun acceptere dem: "hvis de ledsages af bevidstheden om deres overvejende grimhed" (ibid. 40-41). Og dette, hævder han, gælder også forberedelsen til krig. Han giver et militært eksempel og hævder, at de øvelser, soldater udfører før et slag, kræver mindre af dem end slaget selv. Her er en vis uoverensstemmelse mellem øvelsen og det virkelige fænomen tilladt, men kun hvis soldaterne er bevidste om uoverensstemmelsen.

Hvis æstetiske øvelser indgår i både kunsten og krigen helt tilbage fra grundlæggelsen af æstetikken som disciplin, har samtidens militær-æstetiske regime forvandlet deres karakter og funktion. På den ene side har designere af moderne krigsspil ubevidst fulgt forskrifterne i Baumgartens æstetiske teori. VR-krigsspil er æstetiske træningsredskaber, som optimerer sanseapparatet til militære formål. Og de detaljerede immersive virtuelle miljøer, som er blevet udviklet gennem årene, kan nu hensætte rekrutterne i situationer, som minder meget om dem, de vil befinde sig i i felten. For så vidt forsøger de faktisk at kræve lige så meget af rekrutterne i øvelserne som i den efterfølgende kamp.

På den anden side er de designet til at producere grimme tanker. Den reduktion af kompleksitet og variabilitet til et fast antal stereotyper og former, som går forud for spillet, etablerer et antal mentale skemaer, der bestemmer, hvad soldaterne ser i felten. I stedet for at sensibilisere soldaterne til at se det, som Baumgarten kalder "UBERTAS AESTHETICA" - verdens æstetiske rigdom - træner simulationerne dem i hurtige og effektive måder at kategorisere objekter (ibid. 92-93). I modsætning til hvad ICT hævder, ligger spillenes rationale faktisk ikke i en komplet mimesis, men i etableringen af forskelle mellem modellen og virkeligheden. Målet er ikke at skabe det mest realistiske spil, men at etablere og indprente en afvigende model - de kuraterede virtuelle billeder og spillets symbolske form - som så efterfølgende kan appliceres til faktiske fænomener. Med andre ord er målet ikke bare at gøre simulationer mere realistiske, men også at gøre krigens frygtelige realitet mindre virkelig. Affektivt formateret til en tilstand af ligegyldighed kan soldaterne tage billederne og spillemodus med sig på missionerne i Afghanistan og Irak og derved filtrere den faktiske krigserfaring gennem en kontrolleret fiktions skemaer. Hvor Baumgarten forsøger at kultivere sanserne ved hjælp af æstetiske øvelser, kontrollerer moderne krigsspil sanserne og formaterer dem efter et begrænset antal skabeloner programmeret ind i softwaren. På trods af de moderne krigsspils øgede realisme er relationen mellem sindet og verden designet til at være grim.

Den æstetiske administration i samtidige krigsspil minder om den proces, der udspiller sig i genkendelsen, sådan som John Dewey beskriver den. I Art as Experience skelner han mellem perception og genkendelse i et forsøg på at forstå det æstetiske i kunsten og i livet. Hvor æstetikken vækker perceptionen til live og lader den udvikle sig frit for at få os til at opleve noget nyt og uventet, opererer genkendelsen omvendt: Det nye presses ind i et allerede eksisterende skema, som reducerer perceptionen til det velkendte og eliminerer muligheden af at se noget nyt. Genkendelsen fungerer som et filter, der kun lader dét passere til bevidstheden, som allerede er der, eller som minder tilstrækkeligt meget om det til at matche en 
af dens skabeloner. Med Deweys egne ord: "In recognition we fall back, as upon a stereotype, upon some previously formed scheme" (Dewey 2005, 54). I stedet for at se det, der er, bliver perceptionen afbrudt af et bestemt formål, som fx om vi, i Deweys civile eksempel, skal hilse på eller undgå personen, vi genkender på gaden.

Ved at genkende terrænet, temporaliteten, objekterne, fjenden, den operative logik i felten som dem, der blev indprentet af spillet, bliver soldaternes æstetiske perception bremset og begrænset af skabelonerne i softwareprogrammet. Afghanistan genkendes som Virtual Afghanistan, og missionen i Iraq er endnu en gentagelse af missionen gennemført adskillige gange i Virtual Iraq. Den militære æstetik har derfor den omvendte funktion af æstetikken hos Rancière, Baumgarten og Dewey. Med krigssimulationerne overtager og tilpasser militæret æstetikken til sine egne formål og forvandler perception til genkendelse uden at gøre soldaterne bevidste om, hvad der foregår. Spillenes øgede realisme skaber nu et univers, der er så plausibelt, at det kan sløve bevidstheden om skellet mellem spillet og virkeligheden. Det er i det mindste det ideal, som spilindustrien har sat sig. Med mottoet fra firmaet 3-D Realms: "Reality is our Game." Felix aestheticus i uniform bliver trænet til at tænke grimt uden at vide det. Ved at neutralisere æstetikkens kraft til at udvikle alternative beskrivelser og sansninger af verden har officielle militærinstitutioner i stedet forvandlet æstetikken til et redskab til at indprente og implementere et præprogrammeret æstetisk regime: en fast konfiguration af verden, en taktisk, militariseret måde at se, føle og handle på.

Rancière undersøger ikke i første omgang politik i form af krig. Han undersøger heller ikke kunst og æstetik i form af computerspil. ${ }^{14}$ Men han, Dewey og Baumgarten tager alle sanseerfaringen som fundamentet for deres æstetiske teorier. Det, militæret har indset, og det, som forklarer samarbejdet med underholdningsindustrien og millionkontrakterne med institutioner som ICT, er, hvor enormt effektive de immersive VR computerspil er til at skabe og administrere denne erfaring. Selvom de traditionelle æstetiske felter såsom litteratur, kunst og film har en helt anden status end computerspil og simulationer, er det det samme underliggende princip, som tillader Rancière at betragte kunsten som et mulighedsrum for dissens, og som har fået militæret til at absorbere æstetikken ind i dets egen sfære og forvandle den til et krigsredskab.

\section{Simuleret erfaring}

Fremkomsten af den militære æstetik har et antal konsekvenser for begrebet "krigserfaring" i tidsalderen for dens virtuelle reproducerbarhed. I de senere år har Peter Sloterdijk undersøgt, hvordan "træning" eller "Üben” er blevet en dominerende kulturel form i vestlige samfund. Med begrebet "Anthropotechnik" har han samlet et antal praksisser og teknologier, som bliver anvendt til at træne og rekonfigurere mennesker (Sloterdijk 2009, 2010). Immersive VR-krigsspil kan ses som en særlig udgave af en sådan mennesketeknologi for så vidt, at de forsøger at rekonfigurere og træne soldater ved at skabe faktisk erfaring med virtuelle midler. Det er nu værd at lægge mærke til de mange små, men væsentlige forskelle mellem erfaring genereret af simulationer og traditionelle erfaringsbegreber. På den ene 
side regner vi ofte "det nye" som et centralt element i erfaringen. Som Axel Honneth skriver:

4 We have an "experience" when the situation is so unfamiliar, so novel that we cannot orient ourselves and are surprised by the confusion of our intentions, our knowledge, and our sentiments. In such a situation the meaning of what we encounter is still open, we do not yet possess the intellectual means of interpretation that are necessary to master its irritating complexity. In this sense, experiences are constellations, in which affects and intensions, desires and cognitions constitute a unity that has not yet been disentangled. (Honneth 2007, 17)

Hvis vi imidlertid vender tilbage til en klassisk forståelse af "erfaring," nemlig artiklen "Expérience" i Denis Diderot og Jean le Rond d'Alemberts Encyclopédie (17511772), er det nye underordnet tidens gang og refleksionen. I deres definition er erfaring: "den viden, man har opnået gennem et langt liv kombineret med de refleksioner, man har gjort sig, over det, man har set og over de gode eller dårlige begivenheder, som er hændt" (Diderot og d'Alembert 1756). ${ }^{\text {I5 }}$

På mange måder bevirker træningen i VR-krigsspillet en grundlæggende forvandling af de traditionelle erfaringsbegreber. For det første er VR-simulationen ikke baseret på fortiden, men på fremtidige forventninger. Fra en serie af forestillede fremtider låner den begivenheder, der ikke er blevet oplevet, objekter, der ikke er blevet set, og refleksioner ingen har haft. Og disse forestillede fremtider bliver så realiseret af simulationen for at generere faktiske handlingsmønstre, som kan aktiveres i ikke-virtuelle fremtidige situationer. Forbindelsen mellem simulationens nutid og den efterfølgende operations fremtid er cirkulær - et temporalt kollaps, hvor fremtiden smelter sammen med nutiden, da begge finder sted samtidig, mens soldaterne spiller spillet.

For det andet er simulationen baseret på kompression. Den kondenserer et variabelt sæt af mulige erfaringer. I stedet for at udsætte soldaterne for lange perioder af begivenhedsløs kedsomhed, designer simulationen præcis de erfaringer, der er brug for. Når instruktøren i Serious Games I: Watson is down anbringer sprængladninger og fjendtlige kombatanter med et par klik, skaber han flere begivenheder, end de fleste rekrutter oplever i løbet af uger eller måneder, når de sendes ud. Som en erfaringsteknologi, der kondenserer og optimerer, leverer VR erfaring på steroider, så at sige.

For det tredje er VR-simulationen baseret på gentagelse. Fremtidige missioner genspilles ikke bare igen og igen; ideelt set vil erfaringen af de virkelige begivenheder være en gentagelse af simulationen. Med andre ord vil den være en gentagelse af noget, der aldrig er sket, af en forestillet fremtid, som alligevel er blevet gennemspillet adskillige gange. I VR-krigsspillet vil "det nye" være blevet forebygget. Med Farockis ord: "Somehow these images are very close to an ideal type. I think they are asking reality to be as calculable as these systems are. Of course there can be some contingencies and so on, but you know already, the ambush must be behind the bridge" (ten Brink og Oppenheimer 2012, 76). 
I Clausewitz' militærteori er krigens epistemologiske orden gennemsyret af kontingens og probabilistiske begivenheder. Han hævder ligefrem, at "tre fjerdedele af det, som handling i krig hviler på, befinder sig i en tåge af større eller mindre usikkerhed" (Clausewitz 1980, 233). Overbevisningen om, at teknologi og informationsnetværk kunne sikre hæren en nærmest perfekt lokal videnssituation viste sig at være en af de store fejltagelser i Afghanistan (Farrell, Rynning og Terriff 2012, 286-87). Men VR-simulationerne synes at antyde, at de fleste uforudsete hændelser er taget med i beregningen. Som en kommentator formulerer det: "Previously, soldiers would rely on aerial photography, schematics, or 'word of mouth' before heading into danger. Now they'll be able to literally play through a mission over and over again with their squad mates until they feel they have everything down" (Gaudiosi 2011). ${ }^{16}$ Da en af de tilsyneladende traumatiserede soldater i VR-terapien genspiller sin faktiske mission i Serious Games, udbryder han "It was so surreal". Det henviser ikke til det teknologiske apparatur, som han er omgivet af, men de faktiske uforudsigelige og uberegnelige begivenheder, som ikke eksisterede i den virkelighed, simulationerne havde skabt. Traumeterapien forsøger så bagefter at fjerne denne kontingenserfaring ved, endnu engang, at gentage den. Omgivet af virtuelle gentagelser bliver den faktiske erfaring ikke elimineret, men reduceret til ganske korte glimt af virkelighed.

Hvad mere er, når vi ser Farockis fire videoinstallationer i sammenhæng, gennemgår vi, beskuerne, den samme proces som soldaterne. Vi bliver forberedt og repareret af immersive teknologier, men vi oplever aldrig krigen. Der er ikke et eneste billede uden for simulationerne og træningslejrene. Fra den virtuelle træning i genkendelse og i kamp i Serious Games I bliver vi i Serious Games II i en animeret sekvens, designet af firmaet Maraizon International, fløjet ud i ørkenen til en modelby, en såkaldt MOUT facility (Military Operations on Urban Terrain), kun for at træde ind i den virtuelle verden igen i traumeterapien i Serious Games III. I Farockis installation er den virkelige begivenhed - det vi traditionelt forstår ved krigserfaring - blevet redigeret ud. Dette påfaldende fravær bliver så fremhævet i Serious Games IV. Som en opsummering af de tre andre installationer sammenstiller den forberedelsen til krigen og reparationen efter den, mens den faktiske krigserfaring forsvinder i den glatte overgang fra det ene til det andet præcis to minutter og fem-oghalvtreds sekunder inde i filmen. Som Farocki skriver andetsteds: "When the players and soldiers of today die in fifty or sixty years, they will not remember an old sleigh from their childhood like Citizen Kane; rather, they will remember a veiled woman who walked past them in a simulated city" (Ehmann og Farocki 2011, 24).

Dette temmelig uhyggelige udsagn peger på det ideal, som ligger til grund for samtidens opfindelse og administration af krigserfaringen. Soldaternes oplevelse af krig er hverken en kropslig eller konceptuel viden, som de har fået i kamp, eller en erfaring af det nye og ukendte. Det er produktet af et omhyggeligt kalibreret eksperimentelt apparat. I det militær-æstetiske regime får man ikke længere krigserfaring. Den er designet. 


\section{6. Æstetiske undersøgelser}

Hvor VR-krigsspil opnår deres effektivitet via immersion, går Farockis installationer i den modsatte retning. Den dobbelte projektion tilbyder beskueren to simultane perspektiver. En af skærmene viser rekrutternes immersive perspektiv. Den anden ved siden af hiver os ud af simulationen og giver et andenordens metaperspektiv på det enorme teknologiske apparat, der ligger til grund for og producerer spilsimulationen, såvel som på dets brugere. Med et formentlig ubevidst citat fra Coleridges klassiske udsagn om litteratur siger spiludvikleren Floyd West om æstetikken i et nyt krigsspil, som blev solgt til det amerikanske militær for 57 millioner dollars: "What we're trying to do with infantry squad-level training is suspension of disbelief, and the CryEngine 3 is the best video game technology on the market today [min fremhævning]" (Gaudiosi 2011). ${ }^{17}$

Farockis installation placerer i stedet beskueren både inde i og uden for installationen og suspenderer dermed vores "suspension of disbelief." Med dens dobbelte projektion fremmedgør og affunktionaliserer installationen den militære æstetik og deaktiverer dens immersive modus. Set udefra mister billederne på skærmen deres gennemsigtighed. De bliver slørede og begynder at træde frem som billeder. I stedet for at se billeder af verden, ser vi en verden af billeder. Serious Games I-IV udstiller dermed samtidens militær-æstetiske management, hvor man kan opleve sin egen $\mathrm{d} ø \mathrm{~d}$ adskillige gange og forvandle den til et irriteret suk, fordi man nu bliver nødt til at vente, indtil man kan spille missionen forfra.

Serious Games I-IV artikulerer således en subtil form for kritik. ${ }^{18}$ At adskille krinein - er en basal operation i enhver form for kritik. Ved at hive beskueren ud af det immersive billede fors $\emptyset$ ger Farockis dobbelte projektion at lave en adskillelse, at etablere et andet synspunkt, et sted udenfor, hvor man kan stå og observere, et sted hvorfra det immersive billedes funktionsmåde bliver synlig. Med sin sammenstilling af de to skærme, hans "soft montage", gør Farocki brug af en teknik, som ofte er blevet anvendt i krigskunsten i de senere år. ${ }^{19}$ Det, der adskiller Serious Games I-IV, er sammenstillingen af en førsteordens og en andenordens observation. Farocki søger derved at deaktivere militærets overtagelse af æstetikken og dens instrumentaliserede skematisering af perceptionen. Hvor traditionelle serious games forvandler perception til genkendelse i Deweys forståelse af ordet, går de fire videoinstallationer i den modsatte retning og prøver at omgøre genkendelsens skematisme for at genetablere den perceptive modus. Farockis videoer dvæler ved tilsyneladende trivielle billeder og aktiviteter - næsten ubevægelige soldater, der stirrer på deres skærme, en instruktør, der bevæger en mus henover sin trackpad. De gør beskueren desorienteret og usikker: Hvad er det vi ser? Hvad er det meningen, vi skal se? Hvad er pointen med denne sekvens? Som Thomas Elsaesser (2002) skriver om Farockis værk mere generelt: "a child's sense of surprise is never far away." Serious Games $I$-IV har form af en æstetisk undersøgelse af militære billeder - en undersøgelse, som ikke forsøger at påtvinge beskueren en række faste regler eller principper, men som fremmedgør billederne, der omgiver os, som forstyrrer deres selvindlysende karakter og lader deres betydning hænge i luften. Farocki træner beskueren i at percipere, snarere end at genkende og genintroducerer dermed det, som den militære æstetik har afskaffet: det nye, det fremmede, kontingens, usikkerhed og følelsen af, 
at vores mentale visuelle skemaer kun er skemaer og intet andet. Som et modsvar til de militære billeders naturalisering af skematiseret perception, minder han os om, at det vigtigste ofte bliver skjult af de billeder, der hævder at vise det.

Ludwig Wittgenstein bemærkede engang, at den eneste forskel på spil og viden var deres brug, og han fortsatte: "Hvis folk på Mars førte krig, som vi spiller skak, så ville skakreglerne straks blive taget alvorligt og generalstaben ville blive ligeså optaget af skakspillet, som de nu er af landkortet" (Wittgenstein 1984, 163). Veteranen fra skyttegravene forestillede sig formentlig ikke, at hans skakkrig i det ydre rum engang ville blive realiseret i VR-krigsspillenes simulerede verden. Farocki antyder imidlertid, at trods de moderne krigsspils stadig stigende virkelighedseffekter, så forbliver Wittgensteins eksempel en fiktion. Mere end noget andet er det opfindelsen af sådanne ludiske illusioner og deres stærkt tvetydige karakter, som Farockis æstetiske undersøgelser, hans dobbelte perspektiv på den militære æstetik, synliggør.

Samtidig spørger man sig selv, om det helt lykkes Farocki at vikle sig selv fri af sit materiale. Om installationen ved at reproducere krigsteknologien, ved at kuratere militære billeder på den mest nænsomme vis ikke snarere bevirker militæræstetikkens apoteose som kunst. Med Farockis omfattende brug af militærets egne billeder bliver det uklart, om hans forsøg på at annullere militærets overtagelse af æstetikken med en overtagelse af militærets billeder har den ønskede effekt. Om installationen med andre ord ikke uforvarende kommer til at udvide ekspansionen af det militære felt, så ikke bare kulturindustriens produkter, men også kunsten i sidste ende bliver absorberet af det militær-æstetiske regime. Under optagelserne af Serious Games I-IV blev Farocki og hans hold overvåget, og på et tidspunkt blev en PR-medarbejder fløjet ind fra Pentagon for at holde øje med dem (Ehmann og Eshun 2009, 240). Militæret må have givet tilladelsen til at filme amerikanske træningsfaciliteter og vise det offentligt, fordi de regnede med, at det ville sætte dem $i$ et fordelagtigt lys. Hvordan man end ser på det, demonstrerer installations tvetydighed netop i hvor høj grad, de seneste års teknologiske udviklinger har sløret grænsen mellem krig og æstetik. Næsten opslugt af de billeder, han undersøger, åbner Farocki med Serious Games I-IV for forståelsen af et særdeles velfinansieret militær-æstetisk regime, hvis betydning for fremtidige krige kun ser ud til at vokse.

\section{Noter}

I Denne artikel er baseret på mit bidrag til Boundary 2-konferencen The Militarization of Knowledge, publiceret på engelsk med titlen "Technologies of Experience: Harun Farocki's 'Serious Games' and Military Aesthetics" i Boundary 2, 44:4, s. 155-178.

2 Detaljerede beretninger om åbningen kan man læse i Der Derian 2009 og i Lenoir og Lowood 2005.

3 Et af projekterne hed Flatworld (2001-2007). Se Suchman 2016 for en længere analyse af arkivet.

4 I december 2014 modtog STRIVE "the Army Modeling and Simulation Award." Se http://ict. usc.edu/news/strive-project-receives-2014-army-modeling-and-simulation-award/(tilgået: 13. august, 2018). 
og universiteter. Se http://ict.usc.edu/prototypes/pts/ (tilgået 13. august, 2018).

6 Dette projekt modtog i 2010 prisen for "Outstanding Contributions to the Practice of Trauma Psychology" af American Psychological Association.

7 Den klareste formulering af disse ideer finder man i Kittler 1999. Se også Winthrop-Young 2002.

8 I dag er det blevet reorganiseret under navnet PEO STRI (US Army Program Executive Office for Simulation, Training, and Instrumentation).

9 Designerne vedkender sig åbent forbindelsen. Som Chris Morris, den tekniske manager for eksperimentel krigsførelse på Qinetiq, et britisk våbenfirma, sagde tilbage i 2002, "We've been using flight and vehicle simulations for a long time now [...] However, it is far more difficult to create a realistic synthetic environment for foot soldiers [...] We decided to concentrate on the mental and procedural issues, so we started to look for a computer game we could modify" (Crace 2002). Se også Stahl 2010.

Io Der er også en klar forbindelse til den emotionelle poetik i Hollywood-krigsfilm. Her har instruktører i lang tid gjort brug af en række patosscener eller patosformulaer for at styre biografgængernes affektive respons (Kappelhoff 2013). Hollywood-krigsfilmenes affektive management sigter imidlertid mod den kollektive fornemmelse af et følelsesmæssigt fælleskab snarere end det individuelle traume i krigsspillene, hvor patosscenerne også koreograferes live af soldaterne selv.

II Krigsspillenes historie kan man læse mere om i fx Perla 1990; Pias 2002; Lenoir og Lowood 2005; von Hilgers 2008; Harrigan og Kirschenbaum 2016.

I2 En mere generel genealogi finder man i Stephan Günzels bog om first-person shooter spillene. For ham udgør deres rumlige design fusionen af de to store europæiske visuelle traditioner centralperspektivet og den kartografiske repræsentation (Günzel 2012).

I3 Spillet America's Army, som blev udviklet af den amerikanske hær i 2002, fungerer tydeligvis som et hvervningsredskab. Bare seks år efter, det kom på markedet, var der ni millioner registrerede brugere i verden, og man anslår, at 19 procent af alle amerikanske rekrutter har spillet spillet. På den anden side udgør det en meget subtil form for militær propaganda, der fungerer på samme måde som fx reklamer. Farocki skriver, "In this sense, you introduce the war into the imaginary." Som i krigsfilm er oplevelsen i spillene af farer og vold, "and all these things have become part of the common imaginary" (ten Brink og Oppenheimer 2012, 70). Se også Stahl 2010; Günzel 2012.

I4 For hans kritik af humanitær militær intervention se Rancière 2004b.

I5 "[L]a connoissance acquise par un long usage de la vie, jointe aux reflexions que l'on a faites sur ce qu'on a vû, \& sur ce qui nous est arrivé de bien \& de mal”.

I6 John Gaudiosi skrev artiklen til GamePro, som siden er fusioneret med PC World, og artiklen er ikke længere tilgængelig på hjemmesiden, men kan læses her: https://facepunch.com/showthread.php?t=1092363 (tilgået 13. august, 2018).

I7 Det er standardopfattelsen blandt videospiludviklerne. På Hal Barwood og Noah Falsteins liste af de fire hundrede vigtigste regler i video gaming lyder regel nummer ti "Maintain Suspension of Disbelief." De tilføjer, "In any game which uses or relies on narrative content, the player should be encouraged to suspend their disbelief and become imaginatively involved in the work. Once so engaged, the player should be protected from other elements which might shatter their imaginative experience" (Barwood og Falstein 2006).

I8 Se også Nora Alters begreber om "in/visibility" og "the political im/perceptible" i hendes analyse af Images of War (Alter 1996).

I9 Se fx Shapiro 2011; Väliaho 2014; Verwoert 2011. 


\section{Litteratur}

Alter, Nora M (1996): “The Political Im/perceptible in the Essay Film: Farocki’s 'Images of the World and the Inscription of War"', New German Critique 68, s. 165-192.

Barwood, Hal, og Noah Falstein (2006): "The 400 Project Rule List", www.finitearts.com/ Pages/400page.html (tilgået 13. august 2015).

Baumgarten, Alexander G. (2007): Ästhetik, Hamburg: Felix Meiner Verlag.

Clausewitz, Carl von (1980): Vom Kriege, Bonn: Dümmler.

Crace, John (2002): "War Game”, The Guardian 9. juli 2002.

Der Derian, James (2009): Virtuous War: Mapping the Military-Industrial-Media-Entertainment Complex, New York: Routledge.

Dewey, John (2005): Art as Experience, New York: Perigree.

Diderot, Denis, og Jean le Rond d'Alembert (1756): Encyclopédie, ou Dictionnaire raisonné des sciences, des arts et des métiers, vol. 6, Paris: Chez Briasson.

Dragomirov, M.I (1898): Ocherki, Kiev: Oglobin.

Ehmann, Antje, og Harun Farocki (2011): "Ernste Spiele. Eine Einführung”, Serious Games. Krieg/ Medien/Kunst/War/Media/Art. Ostfildern: Hatje Cantz.

Ehmann, Antje, og Kodwo Eshun (2009): Harun Farocki: Against What? Against Whom? London: Koenig Books.

Elsaesser, Thomas (2002): "Harun farocki: Introduction and dossier", Senses of Cinema 21. juli 2002. www.sensesofcinema.com/2002/harun-farocki/farocki_intro/

Engberg-Pedersen, Anders (2015): Empire of Chance: The Napoleonic Wars and the Disorder of Things, Cambridge: Harvard University Press.

Farrell, Theo, Sten Rynning og Terry Terriff (2012): Transforming Military Power since the Cold War: Britain, France, and the United States 1991-2012, Cambridge/New York: Cambridge University Press. Gaudiosi, John (2011): "Crysis 2 engine enlists with the US Army for new military simulator", GamePro.com. Tilgængelig: https://facepunch.com/showthread.php?t=1092363 (tilgået 13. august 2015). Günzel, Stephan (2012): Egoshooter. Das Raumbild des Computerspiels, Frankfurt am Main: Campus Verlag.

Harrigan, Pat, og Matthew G. Kirschenbaum (2016): Zones of Control. Perspectives on Wargaming, Cambridge: MIT Press.

Hilgers, Philipp von (2008): Kriegsspiele, München: Wilhelm Fink Verlag.

Honneth, Axel (2007): "Verwicklungen von Freiheit. Bob Dylan und seine Zeit", Honneth, Axel et al. (red.): Bob Dylan Ein Kongreß. Frankfurt am Main: Suhrkamp Verlag, s. 15-29.

Institute for Creative Technologies (2014): http://ict.usc.edu/about/ (tilgået 2. december 2014). Institute for Creative Technologies (2015a): http://ict.usc.edu/prototypes/pts/. (tilgået 11. januar 2015

Institute for Creative Technologies (2015b): http://ict.usc.edu/prototypes/strive/ (tilgået 11. januar 2015

Kappelhoff, Hermann (2013): "Der Krieg im Spiegel des Genrekinos. John Fords They were expendable”, Kappelhoff et al. (red.): Mobilisierung der Sinne. Der Hollywood-Kriegsfilm zwischen Genrekino und Historie, Berlin: Vorwerk 8, s. 184-227.

Kittler, Friedrich (1999): Gramophone, Film, Typewriter, Stanford: Stanford University Press.

Lenoir, Timothy, og Henry Lowood (2005): “Theaters of War: The Military-Entertainment Complex", Schramm, Helmar et al. (red.): Collection, Laboratory, Theater: Scenes of Knowledge in the 17th Century, Berlin/New York: de Gruyter, s. 427-456. 
Opiz, Johann Ferdinand (1806): Das Opiz'sche Kriegsspiel, ein Beitrag zur Bildung künftiger und zur Unterhaltung selbst der erfahrensten Taktiker, Halle: Hendel.

Perla, Peter P. (1990): The Art of Wargaming, Annapolis: Naval Institute Press.

Pias, Claus (2002): Computer-Spiel-Welten, Zürich: Diaphanes.

Rancière, Jacques (2000): Le Partage du sensible: Esthétique et politique, Paris: La Fabrique.

Rancière, Jacques (2004a): Malaise dans l'esthetique, Paris: Editions Galilée.

Rancière, Jacques (2004b) "Who is the Subject of the Rights of Man?", The South Atlantic Quarterly 103.2-3, s. 297-310.

Shapiro, Michael J. (2011): “The Presence of War: 'Here and Elsewhere.”. International Political Sociology 5, s. 109-125.

Simmel, Georg (1972): "The Metropolis and Mental Life", Levine N., Donald (red.): On Individuality and Social Forms, Chicago: The University of Chicago Press.

Sloterdijk, Peter (2009): Du mußt dein Leben ändern. Über Anthropotechnik, Frankfurt am Main: Suhrkamp Verlag.

Sloterdijk, Peter (2010): Scheintod im Denken. Von Philosophie und Wissenschaft als Übung, Berlin: Suhrkamp Verlag.

Stahl, Roger (2010): Militainment, Inc. War, Media, and Popular Culture, New York/London: Routledge.

Stiegler, Bernhard (2014): Symbolic Misery, Volume 1: The Hyperindustrial Epoch, Cambridge: Polity Press.

Suchman, Lucy (2016): “Configuring the Other: Sensing War through Immersive Simulation”, Catalyst: Feminism, Theory, Technoscience 2.1, s. 1-36.

ten Brink, Joram, og Joshua Oppenheimer (2012): Killer Images. Documentary Film, Memory and the Performance of Violence, New York: Wallflower Press.

Väliaho, Pasi (2014): Biopolitical Screens: Image, Power, and the Neoliberal Brain, Cambridge: MIT Press.

Van Creveld, Martin (2000): The Art of War: War and Military Thought, London: Cassell.

Verwoert, Jan (2011): "See What Shows - On the Practice of Harun Farocki”, Dziewior, Yilmaz (red.): Harun Farocki: Weiche Montagen/Soft Montages, Bregenz: Kunsthaus Bregenz, s. 16-34.

Winthrop-Young, Geoffrey (2002): "Drill and Distraction in the Yellow Submarine: On the Dominance of War in Friedrich Kittler's Media Theory", Critical Inquiry 28, s. 825-54.

Wittgenstein, Ludwig (1984): Wittgenstein und der Wiener Kreis, Frankfurt am Main: Suhrkamp Verlag. 